\title{
The expression of p63 is associated with the differential stage in nasopharyngeal carcinoma and EBV infection
} Can Guo ${ }^{1,2}$, Zhi-Gang Pan ${ }^{1,2}$, Da-Jiang Li 1,2, Jing-Ping Yun ${ }^{1,3}$, MeiZhen Zheng ${ }^{1,2}$, Zhe-Yu Hu${ }^{1,2}$, Li-Zhen Cheng ${ }^{1,2}$ and Yi-Xin Zeng ${ }^{* 1,2}$

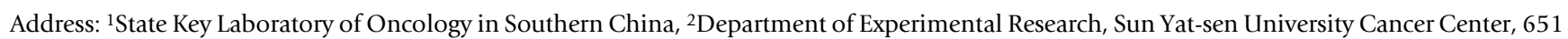
Dongfeng Road East, Guangzhou 510060, China and ${ }^{3}$ Department of Pathology, Sun Yat-sen University Cancer Center, 651 Dongfeng Road East, Guangzhou 510060, China

Email: Can Guo - guocde@gmail.com; Zhi-Gang Pan - zgpan88@hotmail.com; Da-Jiang Li - Idjiang@yahoo.com.cn; JingPing Yun - jpyun@gzsums.edu.cn; Mei-Zhen Zheng - zheng_meizhen@yahoo.com.cn; Zhe-Yu Hu - huzheyu24@163.com; LiZhen Cheng -guocde@gmail.com; Yi-Xin Zeng* - yxzeng2005@163.com

* Corresponding author

Published: 29 May 2006

Journal of Translational Medicine 2006, 4:23 doi:I0.1 I86/1479-5876-4-23
Received: 30 March 2006

Accepted: 29 May 2006

This article is available from: http://www.translational-medicine.com/content/4/I/23

(C) 2006 Guo et al; licensee BioMed Central Ltd.

This is an Open Access article distributed under the terms of the Creative Commons Attribution License (http://creativecommons.org/licenses/by/2.0), which permits unrestricted use, distribution, and reproduction in any medium, provided the original work is properly cited.

\begin{abstract}
Background: Nasopharyngeal carcinoma (NPC) is common among Southern Chinese and the main histology is the undifferentiated carcinoma associated with Epstein-Barr virus (EBV) infection. p63 is a recently proved member of the p53 family based on the structural similarity to p53, but its function in NPC is still unknown. This study was aimed to investigate the association between p63 and NPC.
\end{abstract}

Results: p63 was expressed in 100\%(202/202) of nasopharyngeal carcinoma (NPC) tissues but not in 29 nasopharynx inflammation and 17 non-cancerous nasopharyngeal epidermises on a tissue microarray by immunohistostaining. Further investigation suggested that the p63 expression was associated with the differential stage of NPC: p63 strong staining in Keratinizing squamous cell carcinoma, differentiated non-keratinizing NPC and undifferentiated non-keratinizing NPC presented the percentage of 5/8 (62.5\%), $43 / 48$ (92.5\%) and 50/50 (100\%), respectively. A significant difference $(p=0.00 \mathrm{I})$ existed between the keratinizing and non-keratinizing groups. No pathogenic mutations were detected in $\mathrm{p} 63$ gene in 12 primary NPC tissues and matched peripheral blood lymphocytes (PBL). Half-life measurement study revealed distinct stability of p63 protein in the different cell lines, especially between the carcinoma cell lines with EBV infection and the noncancerous cell lines. The results of immunoprecipitation suggested a direct interaction between Epstein-Barr virus nuclear antigen 5 (EBNA-5) and p63 protein in NPC, and this binding would increase the stability of 63.

Conclusion: Our data suggested p63 might be used as an adjunct diagnostic marker of NPC and contributed a new way to understand the contribution of the EBV in the pathogenesis of NPC.

\section{Background}

Nasopharyngeal carcinoma (NPC) is an epithelial cancer, the histology of which ranges from well-differentiated, keratinizing squamous cell carcinoma to undifferentiated, non-keratinizing carcinoma according to the World Health Organization (WHO) histological classification of 
the tumors. The etiology of NPC is thought to be associated with genetic susceptibility, Epstein-Barr virus (EBV) infection and some other environmental factors [1-5]. NPC has remarkable geographic and population differences in incidence. In the high incidence area - Southern China, $90 \%$ of the NPC patients are undifferentiated, and virtually all nonkerotinizing undifferentiated NPC are associated with EBV $[1,6,7]$.

The tumor suppressor gene $\mathrm{p} 53$ is mutated in more than $50 \%$ of human cancers [8] and $69 \%$ of human head and neck squamous cell carcinomas(HNSCC) [9]; but it was rarely mutate in NPC [10-13]. p63 was identified on the basis of the structural similarity to the p53 tumor suppressor protein. Differing from p53, the p63 gene generates two major types of protein isoforms - TAp 63 and $\Delta \mathrm{Np} 63$ because of two promoters. TA isotypes contain a transactivation domain homologous to that of p53 and can mimic p53 transactivation function, whereas $\Delta \mathrm{N}$ isotypes lack this domain and block reporter activity mediated by p53 and TA-p63 [14-16]. p63 is essential for regenerative proliferation in limb, craniofacial and epithelial development $[17,18]$. Over-expression of p63 was observed in many human cancers, especially these less differentiated tumors [19-24].

Epstein-Barr virus (EBV) is a ubiquitous human herpesvirus associated with the development of both lymphoid and epithelial tumors. [25-27]. Initial studies suggested that it was involved in pathogenesis of NPC $[2,4,28-30]$. The Epstein-Barr virus nuclear antigen 5 (EBNA-5), highly spliced mRNA from the major IR1 (BamHI-W) repeat region of the virus genome, is proved to bind to p53 protein in Burk's lymphocyte [31,32]. The complex of the two proteins can increase the accumulation of the p53 in the nuclear.

Although p63 has high structural similarity according to p53, they do not share similar function. The role of p63 in NPC is still unclear. It was observed in this study that p63 was highly expressed in NPC and associated with the differential stage of NPC. p63 gene took no mutation in NPC, and nevertheless the stability of $\mathrm{p} 63$ protein in the carcinoma cell lines was much higher than that in the non-cancerous cell lines. The results of immunoprecipitation demonstrated that p63 could interact with EBNA5 in vivo, suggesting an important role in the EBV infection and NPC development.

\section{Materials and methods Immunohistochemical assay}

All tissue samples were obtained from the Sun Yat-sen University Cancer center from 2000 to 2004. Immunohistochemistry was performed on 202 undifferentiated NPC samples, 29 nasopharynx inflammation and 17 non-can- cerous nasopharyngeal epidermises on a tissue microarray. Other 106 NPC tissue samples of different histologic subtypes were used for further investigation. All the tissue sections were stained with $\mathrm{H} \& \mathrm{E}$ and microscopically examined to ensure the reliability of the diagnosis. Sections were deparaffinized and rehydrated through xylene and alcohol. After incubated with 3\% hydrogen peroxide for $30 \mathrm{~min}$ at room temperature to block endogenous peroxidase, these sections were then rinsed in $0.01 \mathrm{M}$ sodium citrate buffer ( $\mathrm{pH} \mathrm{6.0)} \mathrm{for} 15 \mathrm{~min}$ at $95^{\circ} \mathrm{C}$ to unmask tissue antigens. Immunostaining was performed with p 63 4A4 (Santa Cruz) at $4{ }^{\circ} \mathrm{C}$ overnight. The sections were then developed according to the manufacturer's recommendations (PV-9000 Polymer Detection System, Golden Bridge International) and counterstained with haematoxylin. The evaluation of p63 expression was assessed semiquantitatively by staining intensity as negative, weak or strongly positive according to Carcangiu's method [33]. These data were all assembled in double blind fashion by two independent investigators without knowing the patients' clinic pathological features and follow-up data.

\section{Cell culture}

C666-1 (a nasopharyngeal carcinoma cell line with EBV infection), CNE-1 (a highly differentiated nasopharyngeal carcinoma cell line), CNE-2 (a poorly differentiated nasopharyngeal carcinoma cell line), HEK293 (a human embryonic kidney cell line) and B95-8 (an EBV-positive Burkitt's lymphoma cell line) were maintained in PRMI 1640 (GIBCO) supplemented with 10\% fetal bovine serum (Hyclone). NP69 (a nasopharyngeal epithelial cells) was cultured by Keratinocyte-SFM (GIBCO) with Bovine Pituitary Extract and rEGF. Cells were incubated with $5 \% \mathrm{CO}_{2}$ at $37^{\circ} \mathrm{C}$.

\section{$P C R$ and DNA sequencing}

Twelve primary NPC tissues and matched peripheral blood lymphocytes (PBL) samples were used for p63 mutation analysis. The PCR products from NPC tissues were firstly purified using the PCR purification Kit (Qiagen) and A-tailed. Then the A-tailed PCR products were ligated into pGEM-T Easy vector (Promega) and propagated in E.coli strain DH5 $\alpha$. At least 10 recombinant positive clones of each sample were sequenced. The PCR products from matched PBL DNA were subjected to direct sequencing. Both the sequencing results from NPC tissue and PBL were analyzed by aligning to the p63 sequence (Genebank:스010153).

\section{Measurement of p63 half-life}

Cycloheximide (CHX) was added at $100 \mathrm{ug} / \mathrm{ml}$ and total protein was isolated at $0,1,2,4,8,16,24$ and 32 hour after drug addition. The expression of p63 was quantitatively determined by Western blot and normalized by $\beta$ - 
actin abundance. The half-life was calculated numerically by using FORECAST (Excel).

\section{Immunoprecipitation}

Cells $\left(3 \times 10^{7}\right)$ were washed twice with ice-cold PBS and dissolved in $200 \mathrm{ul}$ of lysis buffer (20 mM HEPES pH 7.9, $100 \mathrm{mM} \mathrm{NaCl}, 1 \% \mathrm{NP}-40,0.5 \mathrm{mM}$ EDTA, $0.5 \mathrm{mM}$ PMSF). Disrupted the cell lysate by sonication (10s on ice), spun down cell extracts at $12000 \mathrm{rpm}$ for 10 minutes at $4{ }^{\circ} \mathrm{C}$. The immunoprecipitation were then performed according to the Catch and Release v2.0 Kit (Catch and Release v2.0, UPSTATE) recommendations. Lysates were incubated with the anti-EBNA5 monoclonal antibody JF186 (a gift from Karolinska Institute) at $4{ }^{\circ} \mathrm{C}$ overnight on a rotator by using a Catch and Release spin columns. Washed the Column 3 times with $400 \mu$ l of $1 \mathrm{X}$ Wash Buffer, spinning at 5000 rpm 15-30 seconds for each wash. Protein bound to the beads was eluted by Denaturing Elution Buffer containing $0.5 \% \beta$-mercaptoethanol. Proteins were separated by $10 \%$ SDS-PAGE, and then transferred to a PVDF membrane (ROCHE). The membrane was incubated with p63 4A4 (Santa Cruz) at a 1:500 dilution. To further identify this result, we also precipitated cell lysates with p634A4 and then did Western Blot with JF186. Western Blot was done by using the Phototope-HRP Western Blot Detection System kit according to the manufacturer's instructions (Cell Signaling).

\section{Statistical analysis}

Data analysis was performed by using SPSS12.0 software package. Pearson Chi-Square Test was used to test the association between the p63 protein expression and the differential stage of NPC. $P<0.05$ was considered to be statistically significant.

\section{Results \\ Highly expression of $p 63$ in NPC}

All 202 undifferentiated NPC samples showed strong positive staining (Fig 1A), but 29 nasopharynx inflammation (Fig 1C) and 17 non-cancerous nasopharyngeal epidermises (Fig 1D) were negative staining. The different expression patterns of p63 staining in the tissue chip were described in table 1 . We also found p63 was highly expressed in the cells with proliferative potential (Fig 1B) and the shade of staining was correlated to cell differentiation potency. In addition, recent studies revealed that p63 is highly expressed in the basal and suprabasal epithelium [34]. Totally, our data demonstrated the expression pattern of p63 was remarkably different between non-cancerous nasopharyngeal and NPC and revealed that p63 could be used as a valuable diagnostic marker in clinical adjuvant diagnosis of NPC.

\section{The expression of p63 is associated with the differential stage of NPC}

To further investigate the relationship between the p63 expression and the differential stage of NPC, we analyzed 106 NPC tissue samples of different histological subtypes, containing 50 undifferentiated carcinomas, 48 differentiated carcinomas and 8 keratinizing squamous cell carcinomas. The different expression patterns of p63 in different differential stage NPC were displayed in figure 2. All the tissue samples showed nucleus staining, while the intensity of the staining was different with the degree of malignant (Table 2). A significant difference $(p=0.001)$ existed between the keratinizing and non-keratinizing groups. As the keratinizing squamous cell carcinomas was very rarely in the NPC patients of Southern China, we only collected 8 samples in Sun Yat-sen University Cancer center from 2000 to 2004. Although the sample number was few, it indicated a tendency of weak p63 expression in the Keratinizing squamous cell carcinoma. Our data suggested the expression of p63 protein was associated with the differential stage of NPC.

\section{Mutation analysis of p63 in NPC}

Fourteen exons of $p 63$ were amplified and examined in 12 primary NPC tissues and matched PBL samples. Since NPC tissues are confounding with large number of infiltrating lymphocytes, direct sequencing of PCR products may not reveal the real mutation status. We used the PCRcloning sequencing strategy to ensure the purity of the carcinoma cells. Our study indicated the same results to other studies. Unlike p53, p63 mutation was uncommonly found in human cancer cell lines and tumors [3537 , although it was strongly associated with the development abnormality diseases $[17,18,38]$. The results suggested that p 63 gene mutation was not responsible for the high expression of p63 protein.

\section{The expression of p63 is associated with its stability}

Stability of p63 in the different cell lines was shown in Figure 3. A time course using cycloheximide at $100 \mathrm{ug} / \mathrm{ml}$ was used to obtain an accurate determination of the halflife of p63 and demonstrated differences in the degradation of p63 in different cell lines. The expression of p63 was quantitatively determined by Western blot and normalized by $\beta$-actin abundance. The half-life of p63 in different cell lines was described in Figure 4. The interaction of p53 with other proteins is known to alter the stability of p53. In this study, we found the half-life of p63 in the carcinoma cell lines was clearly longer than non-carcinoma cell lines, especially the carcinoma cell lines with EBV infection.

\section{Direct interactions between p63 and EBNA-5}

To further identity the molecular mechanism of high expression of p63, we performed co-immunoprecipita- 


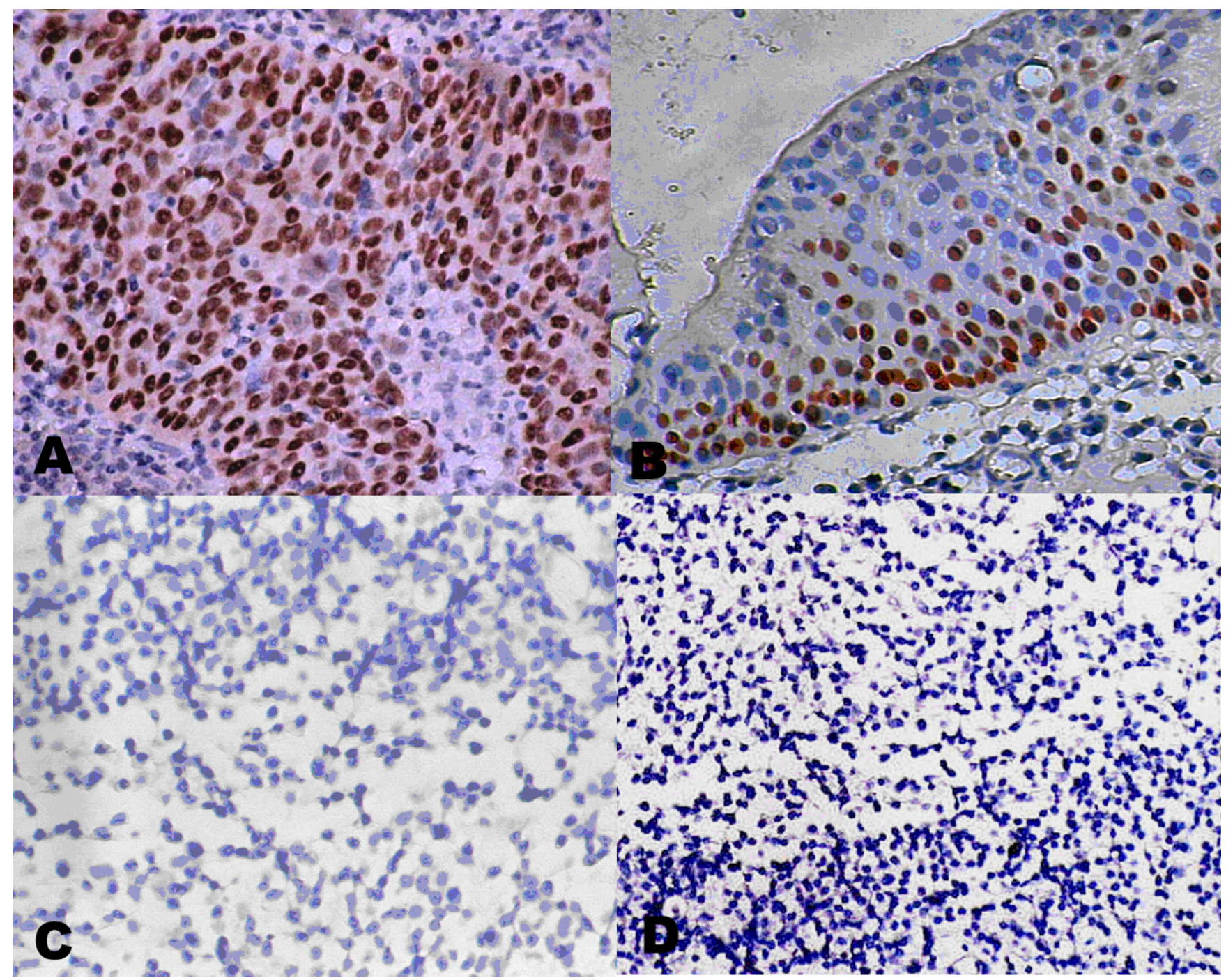

Figure I

Immunohistochemical demonstration of p63 protein expression. Strong positive staining of p63 protein in NPC(A) and the basal layer cells with proliferate potential(B); negative staining of p63 protein in nasopharynx inflammation (C) and noncancerous nasopharyngeal epidermises(D). (All the photomicrographs were taken in high-powered, $\times 400$ ).

tion with p63 and EBNA5. The protein complex of p63 and EBNA-5 were tested in both the C666 cell line and B95-8 cell line, and NP69 was used as a negative control (Fig 3). Like p53, p63 was rarely mutated but take high expression in NPC. High expression of p53 was indicated in inactive form due to the binding with EBNA5 in Burk's lymphocyte [31,32], and the complex of the two proteins led to increased accumulation of p53 in nuclei. p63 have a high amino acid identity to p53. Our study also revealed that the interaction between p63 and EBNA5 might contribute for the stability of p63.

\section{Discussion}

Despite structural and functional similarities between p63 and p53, there are many differences. Inactivation of wild type 553 is indicated in most human cancers due to muta-

Table I: Expression of p63 immunohistochemical staining in the tissue chip

\begin{tabular}{lll}
\hline Nasopharyngeal carcinoma & $n=202$ & strong positive staining \\
Nasopharynx inflammation & $n=29$ & negative staining \\
Non-cancerous nasopharyngeal epidermis & $n=17$ & negative staining
\end{tabular}


Table 2: Expression pattern of p63 in 106 NPC samples with different differentiation status

\begin{tabular}{llcc}
\hline Differentiated status & & Weak staining & Strong staining \\
\hline Keratinizing squamous cell carcinoma & $\mathrm{n}=8$ & $3(37.5 \%)$ & $5(62.5 \%)$ \\
Differentiated non-keratinizing NPC & $\mathrm{n}=48$ & $5(7.5 \%)$ & $43(92.5 \%)$ \\
Undifferentiated non-keratinizing NPC & $\mathrm{n}=50$ & $0(0 \%)$ & $50(100 \%)$ \\
\hline
\end{tabular}

$\left(x^{2}=14.934, \mathrm{df}=2, p=0.00 \mathrm{I}\right)$

tion or interaction of other protein. Previous studies demonstrated that some viral proteins could bind to p53, to prevent its degradation and accumulate in the cell nuclear, and results in high expression. In this study, we found that p63 is highly expressed in NPC, especially the histology of undifferentiated. Considering no mutation detected in
NPC, we concluded that gene mutation was not responsible for the high expression of p63 in NPC. p53 protein is labile and its activity is regulated by its degradation and its level of stability. p53 levels are controlled largely by Mdm2. Mdm2 can also bind with p63, but Mdm2 are not able to repress p63-induced transcription or to affect its

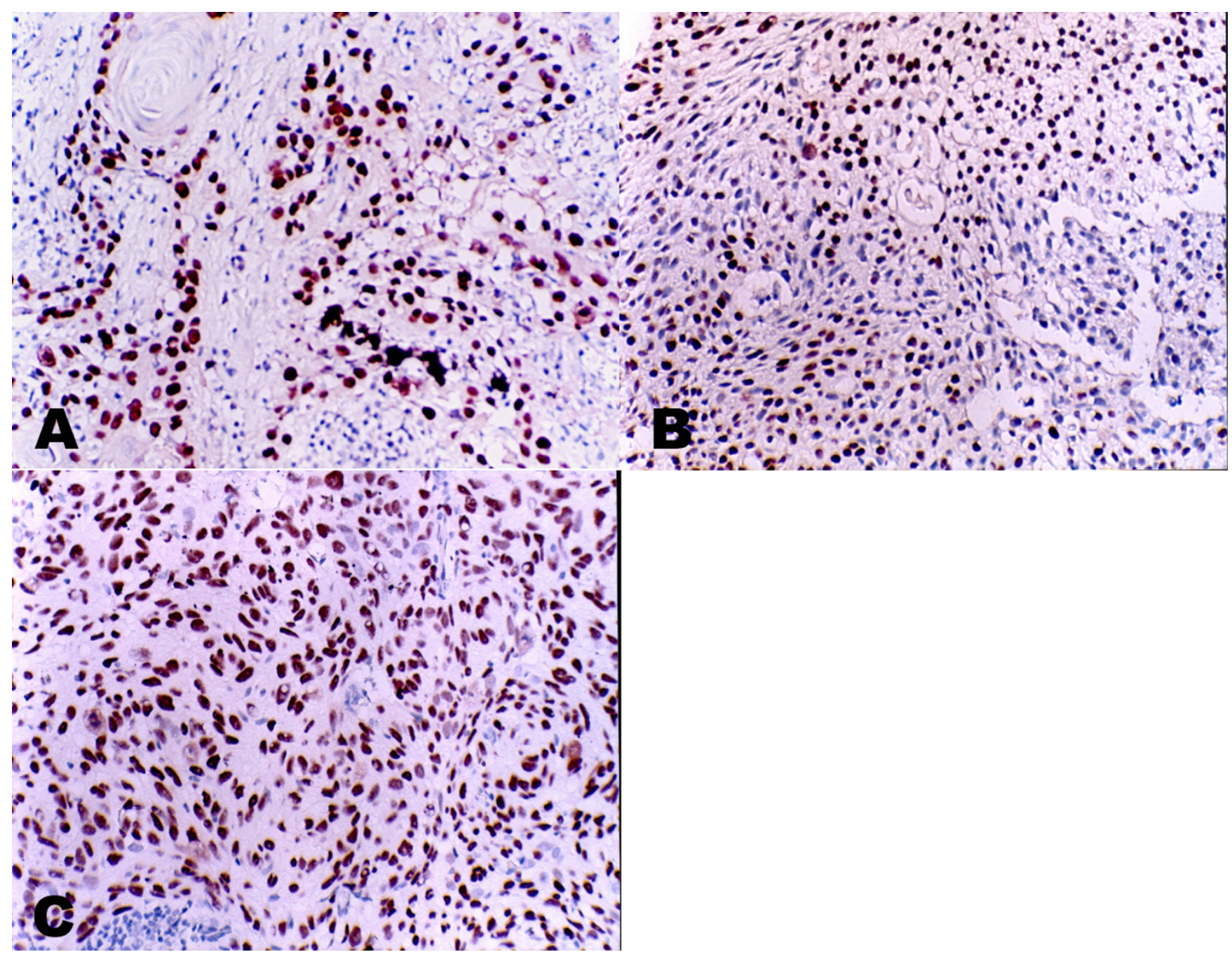

Figure 2

Immunohistochemical demonstration of p63 protein expression in different histology NPC. Strong nuclear staining of $p 63$ in keratinizing NPC (A) differentiated non-keratinizing NPC (B) and undifferentiated non-keratinizing NPC (C)(All the photomicrographs were taken in high-powered, $\times 400)$. The staining intensity is associated with the differential stage of NPC. 


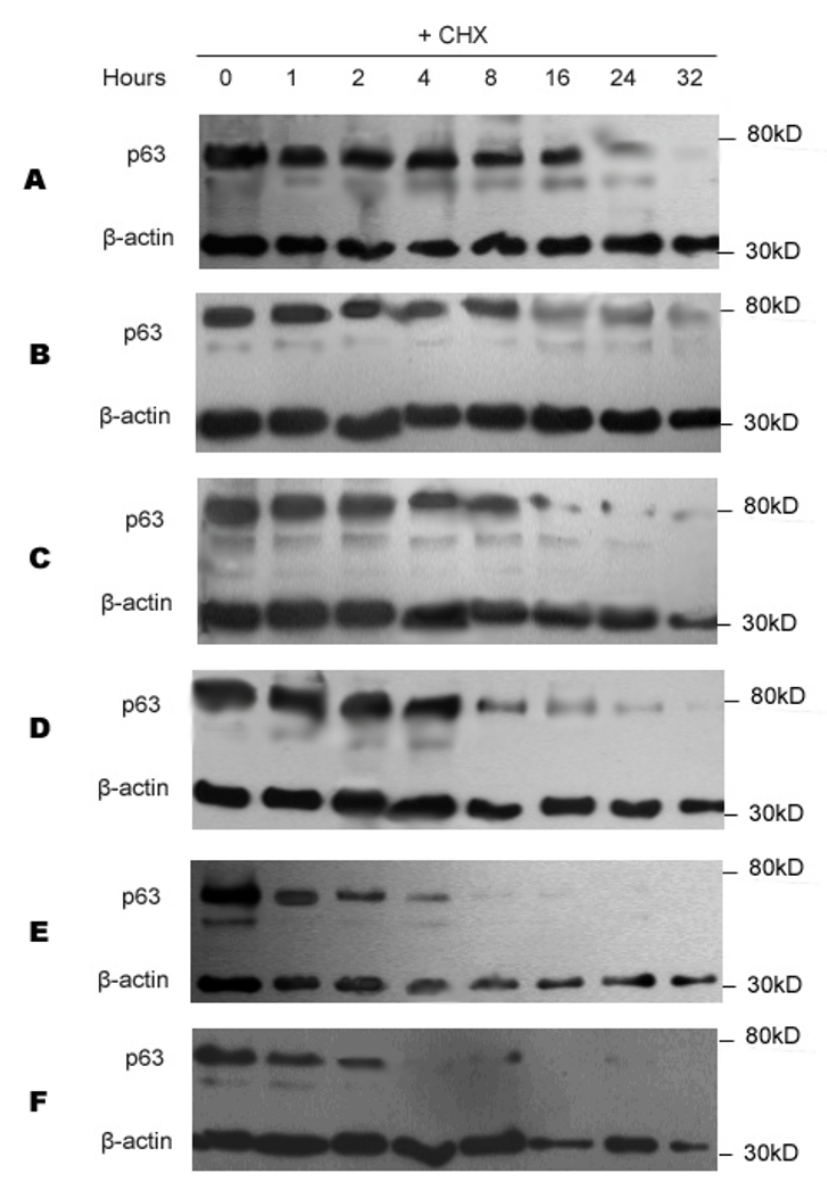

Figure 3

Stability of p63 with $\mathrm{CHX}$ treatment. $\mathrm{CHX}$ was added at $100 \mathrm{ug} / \mathrm{ml}$ and total protein was extracted as indicated. Western blots were performed with $p 63$ and $\beta$-actin in $(A)$ B95-8 cells, (B) C666 cells, (C) CNE2 cells, (D) CNEI cells, (E) NP69 cells, (F) 293 cells.

half-life [39]. In addition, other researchers found that Mdm2 helped increase transcriptional activity and the protein level of p63 [40]. The regulation of the stability of p63 is complex and still poorly understood. Our study suggested a distinct difference of half-life between the carcinoma cell lines with EBV infection and the non-cancerous cell lines. And we found that there is a directly interaction between the EBNA-5 and the p63 protein in NPC by taking the co-immunopreciatiate experiment. These results suggested the interaction with the virally encoded protein might contribute to increase the stability of p63. Although the expression pattern of the p63 is researched generally, the mechanism of its high expression remains an enigma. Therefore, our research was providing a novel mechanism for the degradation of p63.

The role of p63 in tumorigenesis is complex. p53 was firstly heralded as an oncogene because of its potent trans-

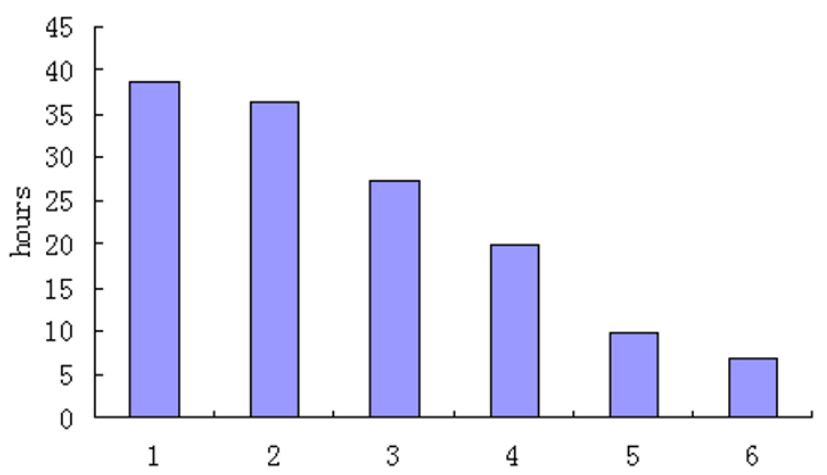

Figure 4

Half-life of p63 in the different cell lines. The half life of p63 was 38.64h, 36.42h, 27.47h, 19.74h, 9.76h, 6.93h accordingly to B95-8cells, C666 cells, CNE2 cells, CNEI cells, NP69 cells and 293 cells respectively.

formation capabilities and its robust expression in human tumors. However, it was later discovered that only mutant p53 was oncogenic, and that wild type p53 was a tumor suppress gene. Differing from p53, p63 was rarely mutated or inactivated in human cancers, and p63 null mice failed to develop tumors $[17,18,37]$. Our results showed that the p63 protein was highly expressed in NPC and associated with its differential stage, suggesting it to be a valuable diagnostic marker. In South China, the area with high incidence of NPC, $90 \%$ of the NPC patients are undifferentiated, and nonkerotinizing undifferentiated NPC are all associated with EBV $[1,6,7]$. NPC is unique in that the exogenous EBV is present exclusively in the cancer cells, but not in the surrounding normal tissues, providing

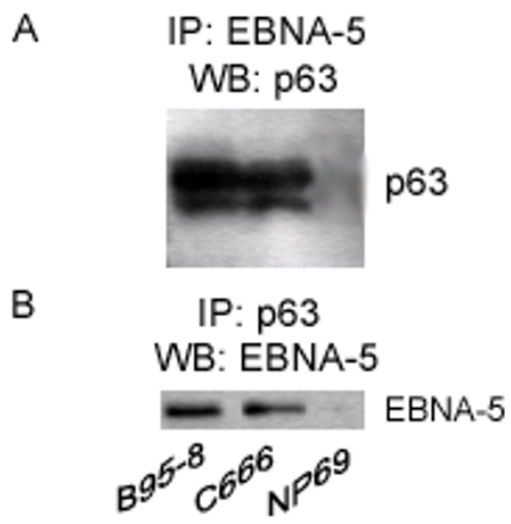

Figure 5

Co-immunoprecipitation of p63 and EBNA-5. (A) Cell extract were precipitated with the JFI86 and analysed by Western blot with p63. (B) Cell extract were precipitated with the p63 and analysed by Western blot with JFI86. 
an obvious exploitable opportunity [41]. The expression of p63 takes a completely identity of the presentation of EBV. p63 is highly expressed in the carcinoma cells but not in the normal tissues. This is strong evidence to demonstrate the association between the p63 and EBV.

EBV plays an etiological role in the development of NPC. However, how EBV contributes to NPC formation has not been clearly elucidated. Our results proved that the interaction of p63 and EBNA5 in vivo. EBNA-5 was required for B-cell transformation [42] and efficient outgrowth of lymphoblastoid cell lines (LCLs) [43]. Previous studies suggested that it was mainly co-operated with EBNA-2 [44]. EBNA2 can transactivating the latent membrane protein 1 of EBV (LMP1) [45]. Numerous studies have revealed the oncogenic properties of LMP1, including increasing cell proliferation and invasion; inhibiting apoptosis, senescence and differentiation [46-49]. LMP1 is conformed as EBV oncogene in NPC $[50,51]$. We think the p63 may impose an impact on LMP1 by interaction with EBNA2. But how they exert the effect and what are the detailed mechanisms making them to function are still waiting to be discovered.

Totally, our study identified a high expression of p63 in NPC cells and the level of p63 expression was correlated with the differential stage of NPC, suggested p 63 might be used as an adjunct diagnostic marker of NPC. And the interaction between p63 and EBNA5 might contribute for the stability of p63. These results implied an important role of p63 gene in development of NPC and prompted a new way to understand the contribution of the EBV in the pathogenesis of NPC.

\section{Authors' contributions}

YXZ and GC were responsible for study design. CG performed the experiments and drafted the manuscript. ZGP and DJL contributed to collection of specimens and mutation analysis. JPY helped in the immunohistochemical assay. MZZ and YZH participated in the data analysis and western-blot. LZC helped in the cell culture. All authors read and approved the final manuscript.

\section{Acknowledgements}

We thank Professor George Klein and Mia Lowbeer (Microbiology and Tumor Biology Center, Karolinska Institute, Sweden) for sending the antibody JFI86, and Fang Yan (an associate professor of Cancer Center, Sun Yat-sen University) for providing the tissue chip.

\section{References}

I. Hording U, Nielsen HW, Albeck H, Daugaard S: Nasopharyngeal carcinoma: histopathological types and association with Epstein-Barr Virus. Eur I Cancer B Oral Oncol 1993, 29B(2): 137-139.

2. Hildesheim A, West S, DeVeyra E, De Guzman MF, Jurado A, Jones C, Imai J, Hinuma Y: Herbal medicine use, Epstein-Barr virus, and risk of nasopharyngeal carcinoma. Cancer Res 1992, 52(II):3048-305I.
3. Zeng $Y X$, Jia WH: Familial nasopharyngeal carcinoma. Semin Cancer Biol 2002, I 2(6):443-450.

4. Raab-Traub N: Epstein-Barr virus and nasopharyngeal carcinoma. Semin Cancer Biol 1992, 3(5):297-307.

5. Xiong W, Zeng ZY, Xia JH, Xia K, Shen SR, Li XL, Hu DX, Tan C, Xiang J], Zhou J, Deng H, Fan SQ, Li WF, Wang R, Zhou M, Zhu SG, Lu HB, Qian J, Zhang BC, Wang JR, Ma J, Xiao BY, Huang H, Zhang QH, Zhou YH, Luo XM, Zhou HD, Yang YX, Dai HP, Feng GY, Pan $\mathrm{Q}$, Wu LQ, He L, Li GY: A susceptibility locus at chromosome 3p2I linked to familial nasopharyngeal carcinoma. Cancer Res 2004, 64(6): 1972-1974.

6. Choi PH, Suen MW, Huang DP, Lo KW, Lee JC: Nasopharyngeal carcinoma: genetic changes, Epstein-Barr virus infection, or both. A clinical and molecular study of 36 patients. Cancer 1993, 72(I 0):2873-2878.

7. Raab-Traub N, Flynn K, Pearson G, Huang A, Levine P, Lanier A, Pagano J: The differentiated form of nasopharyngeal carcinoma contains Epstein-Barr virus DNA. Int J Cancer 1987, 39(I):25-29.

8. Harris CC, Hollstein M: Clinical implications of the p53 tumorsuppressor gene. N Engl J Med 1993, 329(18): | 3 |8-1327.

9. Ahomadegbe JC, Barrois M, Fogel S, Le Bihan ML, Douc-Rasy S, Duvillard P, Armand JP, Riou G: High incidence of p53 alterations (mutation, deletion, overexpression) in head and neck primary tumors and metastases; absence of correlation with clinical outcome. Frequent protein overexpression in normal epithelium and in early non-invasive lesions. Oncogene 1995, 10(6): 1217-1227.

10. Spruck CH, Tsai YC, Huang DP, Yang AS, Rideout WM, GonzalezZulueta M, Choi P, Lo KW, Yu MC, Jones PA: Absence of p53 gene mutations in primary nasopharyngeal carcinomas. Cancer Res 1992, 52(17):4787-4790.

II. Lo KW, Mok CH, Huang DP, Liu YX, Choi PH, Lee JC, Tsao SW: p53 mutation in human nasopharyngeal carcinomas. Anticancer Res 1992, I2(6B): 1957-1963.

12. Sun Y, Hegamyer G, Cheng YJ, Hildesheim A, Chen JY, Chen IH, Cao $\mathrm{Y}$, Yao KT, Colburn NH: An infrequent point mutation of the p53 gene in human nasopharyngeal carcinoma. Proc Natl Acad Sci U S A 1992, 89(14):6516-6520.

13. Porter MJ, Field JK, Lee JC, Leung SF, Lo D, Van Hasselt CA: Detection of the tumour suppressor gene p53 in nasopharyngeal carcinoma in Hong Kong Chinese. Anticancer Res 1994, I4(3B): I $357-1360$

14. Osada M, Ohba M, Kawahara C, Ishioka C, Kanamaru R, Katoh I, Ikawa $Y$, Nimura Y, Nakagawara A, Obinata M, Ikawa S: Cloning and functional analysis of human $\mathrm{p} 5 \mathrm{I}$, which structurally and functionally resembles p53. Nat Med 1998, 4(7):839-843.

15. Wu G, Nomoto S, Hoque MO, Dracheva T, Osada M, Lee CC, Dong SM, Guo Z, Benoit N, Cohen Y, Rechthand P, Califano J, Moon CS, Ratovitski E, Jen J, Sidransky D, Trink B: DeltaNp63alpha and TAp63alpha regulate transcription of genes with distinct biological functions in cancer and development. Cancer Res 2003, 63(I 0):235I-2357.

16. Yang A, Kaghad M, Wang Y, Gillett E, Fleming MD, Dotsch V, Andrews NC, Caput D, McKeon F: p63, a p53 homolog at 3q2729, encodes multiple products with transactivating, deathinducing, and dominant-negative activities. Mol Cell 1998, 2(3):305-316.

17. Yang A, Schweitzer R, Sun D, Kaghad M, Walker N, Bronson RT, Tabin C, Sharpe A, Caput D, Crum C, McKeon F: p63 is essential for regenerative proliferation in limb, craniofacial and epithelial development. Nature 1999, 398(6729):714-7|8.

18. Mills AA, Zheng B, Wang XJ, Vogel H, Roop DR, Bradley A: p63 is a p53 homologue required for limb and epidermal morphogenesis. Nature 1999, 398(6729):708-713.

19. Crook T, Nicholls JM, Brooks L, O'Nions J, Allday MJ: High level expression of deltaN-p63: a mechanism for the inactivation of p53 in undifferentiated nasopharyngeal carcinoma (NPC)? Oncogene 2000, 19(30):3439-3444.

20. Davis LD, Zhang W, Merseburger A, Young D, Xu L, Rhim JS, Moul JW, Srivastava $S$, Sesterhenn IA: p63 expression profile in normal and malignant prostate epithelial cells. Anticancer Res 2002, 22(6C):3819-3825

21. Glickman JN, Yang A, Shahsafaei A, McKeon F, Odze RD: Expression of p53-related protein $\mathrm{p} 63$ in the gastrointestinal tract 
and in esophageal metaplastic and neoplastic disorders. Hum Pathol 200I, 32(II): II57-II65.

22. Park BJ, Lee SJ, Kim Jl, Lee SJ, Lee CH, Chang SG, Park JH, Chi SG: Frequent alteration of $\mathrm{p} 63$ expression in human primary bladder carcinomas. Cancer Res 2000, 60(13):3370-3374.

23. Signoretti S, Waltregny D, Dilks J, Isaac B, Lin D, Garraway L, Yang A, Montironi $R$, McKeon $F$, Loda M: p63 is a prostate basal cell marker and is required for prostate development. Am J Pathol 2000, I 57(6): I769-1775.

24. Massion PP, Taflan PM, Jamshedur Rahman SM, Yildiz P, Shyr Y, Edgerton ME, Westfall MD, Roberts JR, Pietenpol JA, Carbone DP Gonzalez AL: Significance of $\mathbf{p 6 3}$ amplification and overex pression in lung cancer development and prognosis. Cancer Res 2003, 63(2I):7|I3-7|2I.

25. Klein G: Epstein-Barr virus (EBV)-induced transformation of human lymphoid cells and immunosurveillance against lymphoma development. Ann Immunol (Paris) 1973, I 24(3):39|-405.

26. Dunkel VC: In vitro and in vivo studies with Epstein-Barr virus (EBV). A review. Ann Clin Lab Sci 1973, 3(6):424-428.

27. Henle W, Henle G: The Epstein-Barr Virus (EBV) in Burkitt's lymphoma and nasopharyngeal carcinoma. Ann Clin Lab Sci 1974, 4(2): 109-114

28. Niedobitek G: Epstein-Barr virus infection in the pathogenesis of nasopharyngeal carcinoma. Mol Pathol 2000, 53(5):248-254.

29. Liebowitz D: Nasopharyngeal carcinoma: the Epstein-Barr virus association. Semin Oncol I 994, 2 I (3):376-38I.

30. Raab-Traub N: Epstein-Barr virus in the pathogenesis of NPC. Semin Cancer Biol 2002, I 2(6):43 I-44I.

31. Szekely L, Selivanova G, Magnusson KP, Klein G, Wiman KG: EBNA5 , an Epstein-Barr virus-encoded nuclear antigen, binds to the retinoblastoma and p53 proteins. Proc Natl Acad Sci U S A 1993, 90(I 2):5455-5459.

32. Ring CJ, Jones MD, Griffin BE: Alternative splicing determines the carboxy terminus of the Epstein-Barr virus nuclear antigen 5 species expressed in the Burkitt's lymphoma cell line Daudi. J Gen Virol 1992, 73 ( Pt 10):27 I5-27I9.

33. Carcangiu ML, Chambers JT, Voynick IM, Pirro M, Schwartz PE: Immunohistochemical evaluation of estrogen and progesterone receptor content in 183 patients with endometria carcinoma. Part I: Clinical and histologic correlations. Am J Clin Pathol 1990, 94(3):247-254.

34. Parsa R, Yang A, McKeon F, Green H: Association of p63 with proliferative potential in normal and neoplastic human keratinocytes. J Invest Dermatol I999, I I 3(6): 1099-I I05.

35. Sunahara M, Shishikura T, Takahashi M, Todo S, Yamamoto N, Kimura H, Kato S, Ishioka C, Ikawa S, Ikawa Y, Nakagawara A: Mutational analysis of p5IA/TAp63gamma, a p53 homolog, in non-small cell lung cancer and breast cancer. Oncogene 1999 , | 8(25):376|-3765.

36. Nishi H, Isaka K, Sagawa $Y$, Usuda S, Fujito A, Ito H, Senoo M, Kato $\mathrm{H}$, Takayama M: Mutation and transcription analyses of the p63 gene in cervical carcinoma. Int J Oncol 1999, I5(6): I I49-1 I 53.

37. Hagiwara K, McMenamin MG, Miura K, Harris CC: Mutational analysis of the p63/p73L/p5 I/p40/CUSP/KET gene in human cancer cell lines using intronic primers. Cancer Res 1999, 59(I7):4165-4I69.

38. Celli J, Duijf P, Hamel BC, Bamshad M, Kramer B, Smits AP, NewburyEcob R, Hennekam RC, Van Buggenhout G, van Haeringen A, Woods CG, van Essen AJ, de Waal R, Vriend G, Haber DA, Yang A, McKeon $F$, Brunner HG, van Bokhoven $H$ : Heterozygous germline mutations in the p53 homolog p63 are the cause of EEC syndrome. Cell 1999, 99(2):143-153.

39. Little NA, Jochemsen AG: Hdmx and Mdm2 can repress transcription activation by $\mathbf{p 5 3}$ but not by p63. Oncogene 200I, 20(33):4576-4580.

40. Calabro V, Mansueto G, Parisi T, Vivo M, Calogero RA, La Mantia G: The human MDM2 oncoprotein increases the transcriptional activity and the protein level of the p53 homolog p63. J Biol Chem 2002, 277(4):2674-268I.

4I. Liu FF: Novel gene therapy approach for nasopharyngeal carcinoma. Semin Cancer Biol 2002, I 2(6):505-5 I5

42. Mannick JB, Cohen Jl, Birkenbach M, Marchini A, Kieff E: The Epstein-Barr virus nuclear protein encoded by the leader of the EBNA RNAs is important in B-lymphocyte transformation. J Virol I99|, 65(I 2):6826-6837.
43. Allan G], Inman G], Parker BD, Rowe DT, Farrell PJ: Cell growth effects of Epstein-Barr virus leader protein. J Gen Virol 1992, 73 ( Pt 6):|547-|55|

44. Harada S, Kieff E: Epstein-Barr virus nuclear protein LP stimulates EBNA-2 acidic domain-mediated transcriptional activation. J Virol I997, 7 I(9):66 I I-66 I8.

45. Wang F, Tsang SF, Kurilla MG, Cohen Jl, Kieff E: Epstein-Barr virus nuclear antigen 2 transactivates latent membrane protein LMPI. J Virol 1990, 64(7):3407-3416.

46. Henderson S, Rowe M, Gregory C, Croom-Carter D, Wang F, Longnecker R, Kieff E, Rickinson A: Induction of bcl-2 expression by Epstein-Barr virus latent membrane protein I protects infected B cells from programmed cell death. Cell |99|, 65(7): $1107-1 \mid 15$

47. Dawson CW, Rickinson AB, Young LS: Epstein-Barr virus latent membrane protein inhibits human epithelial cell differentiation. Nature 1990, 344(6268):777-780.

48. Fahraeus R, Rymo L, Rhim JS, Klein G: Morphological transformation of human keratinocytes expressing the LMP gene of Epstein-Barr virus. Nature 1990, 345(6274):447-449.

49. Mosialos G, Birkenbach M, Yalamanchili R, VanArsdale T, Ware C, Kieff E: The Epstein-Barr virus transforming protein LMPI engages signaling proteins for the tumor necrosis factor receptor family. Cell 1995, 80(3):389-399.

50. Tsao SW, Tramoutanis G, Dawson CW, Lo AK, Huang DP: The significance of LMPI expression in nasopharyngeal carcinoma. Semin Cancer Biol 2002, I 2(6):473-487.

51. Kondo S, Wakisaka N, Schell MJ, Horikawa T, Sheen TS, Sato H, Furukawa M, Pagano JS, Yoshizaki T: Epstein-Barr virus latent membrane protein $I$ induces the matrix metalloproteinase-I promoter via an Ets binding site formed by a single nucleotide polymorphism: enhanced susceptibility to nasopharyngeal carcinoma. Int J Cancer 2005, I I 5(3):368-376.

Publish with Biomed Central and every scientist can read your work free of charge

"BioMed Central will be the most significant development for disseminating the results of biomedical research in our lifetime. "

Sir Paul Nurse, Cancer Research UK

Your research papers will be:

- available free of charge to the entire biomedical community

- peer reviewed and published immediately upon acceptance

- cited in PubMed and archived on PubMed Central

- yours - you keep the copyright 